\title{
Nurses' Resilience During Covid-19 Pandemic: A Scoping Review
}

\author{
Hery Yuliani Astuti', Suhartini Ismail2*, Andrew Johan ${ }^{3}$ \\ ${ }^{11}$ Master of Nursing Student, Faculty of Medicine Universitas Diponegoro, Indonesia \\ ${ }^{2 *}$ Emergency and Critical Care Nursing Division, Nursing Department Faculty of Medicine \\ Universitas Diponegoro, Indonesia
}

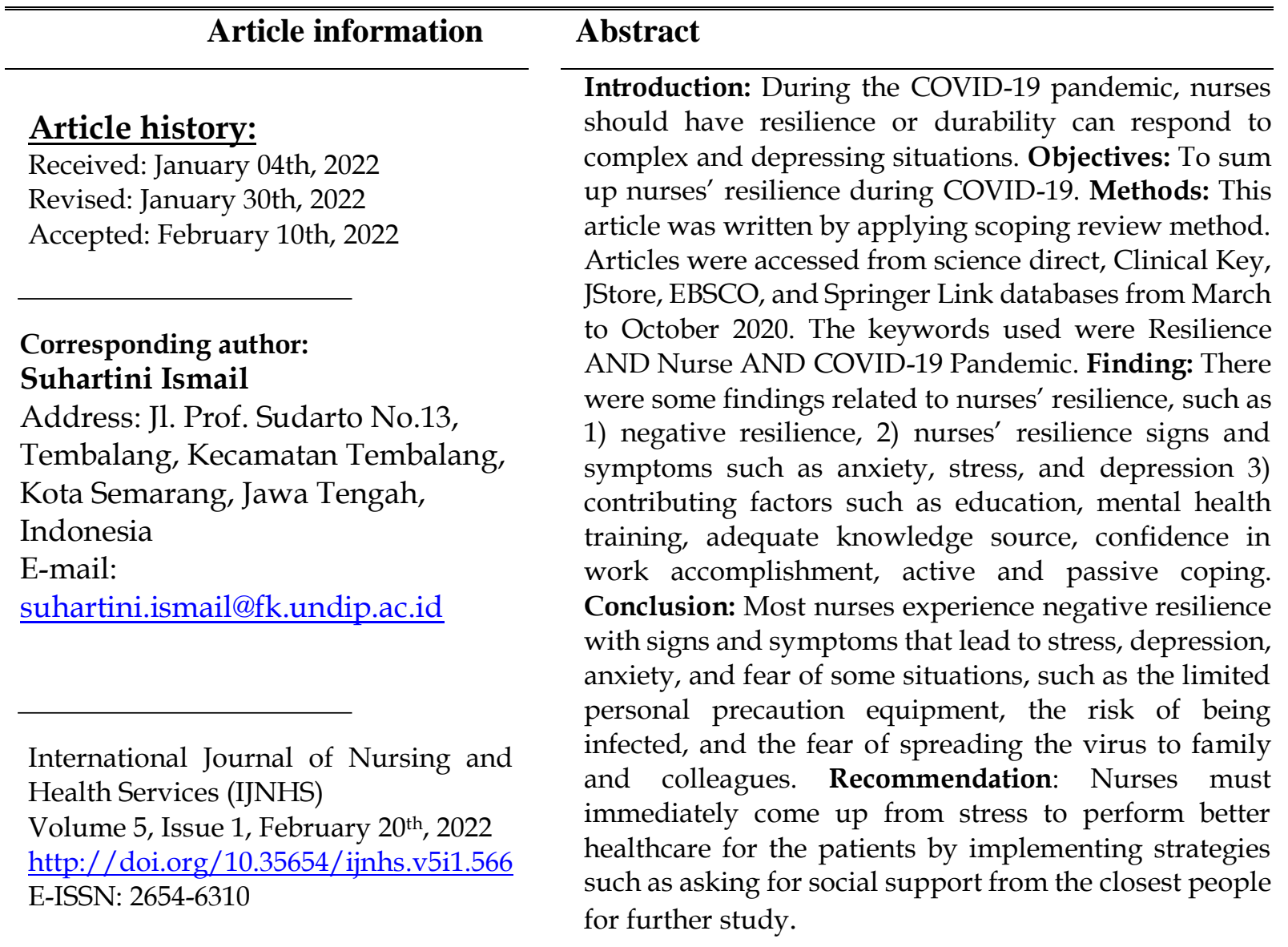

Keywords: COVID-19 pandemic, resilience nursing

This is an Open Access article distributed under the terms of the Creative Commons Attribution 4.0 International License CC BY -4.0 


\section{INTRODUCTION}

During the COVID-19 pandemic, nurses face many challenges, such as working professionally while suppressing the COVID-19 case number in the hospital (1). The challenges could turn into stress which affects nurses' performance. Meanwhile, nurses endure physical and moral burdens in accomplishing their work and avoiding any problems. The problems come from some components, such as colleagues, management, work environment, supervisor, and various patients' condition. Thus nurses are required to endure any conditions(2). Those conditions need nurses to have strength in enduring hardships and challenges. The power is what we call resilience (1).

Resilience or strength refers to responding to difficult and stressful conditions. During the COVID-19 pandemic, nurses have to serve the patients despite conditions and the fear of being infected. Nurses' health is at risk as they work in an extreme situation related to rapid COVID-19 spread, heavy stress, the uncertainty on when the pandemic is over, and the stigma given by the society, which overburdens nurses' endurance. Low resilience leads to negative coping(3).

To cope with stress, nurses must adapt to the existing condition, maintain a healthy mentality, and build psychological strength to keep productivity and perform efficiently and safely to the patients (4). Psychological strength plays a vital role in improving self-strength to fight stress, develop effective coping strategies, set situations better, and give better service to patients (5).

Some previous research showed a different representation of resilience. Thus, indepth exploration about resilience in nurses during the COVID-19 pandemic is highly required through scoping review, which aims to find out the comprehensive description related to nurses' resilience during the COVID19 pandemic.

\section{OBJECTIVE}

This scoping review was aimed to summarize the nurses' resilience during the COVID-19 pandemic.

\section{METHODS \\ Design}

The method used in this study was scoping review. The framework used by Arksey and O'Malley for scoping review consists of five steps: research question and object, relevant article identification, article selection, data graphic making, arranging, summarizing, and reporting the finding(6). The research question in this research was "How is the representation of nurses' resilience during the COVID-19 pandemic?".

\section{Databases}

Strategy in searching the literature, the data based from science direct, Clinical Key, JStore, EBSCO, and Springer Link were used from March to October 2020.

\section{Keywords}

The keyword used was completed with Boolean "OR/AND" with the keyword: Resilience AND Nurse AND COVID-19 Pandemic.

Literature Identification the scoping review, an independent literature search, was done through trusted data based. The retrieved article was then analyzed, especially on the difference and duplication.

Figure 1 explains the identification and article choosing process by using Preferred Reporting Items for Systematic review and Meta-Analyses Extension for Scoping Reviews (PRISMA-SCR) (9).

\section{RESULTS}

Four hundred twenty-six articles were retrieved as the literature were 12 articles from science direct, 86 articles for Clinical Key, 49 articles from EBSCO, 47 articles from JStore, 232 articles from Springer Link. There were 102 same articles from the database, excluding those articles, leaving 324 articles.

Out of 324 articles, 168 articles were excluded as they only include theory, no correlation between abstract and topic, and not an original article. The article screening obtained 138 articles related to resilience explanation were excluded, leaving ten complete articles. 
and Iran(7-9). The resilience score obtained by
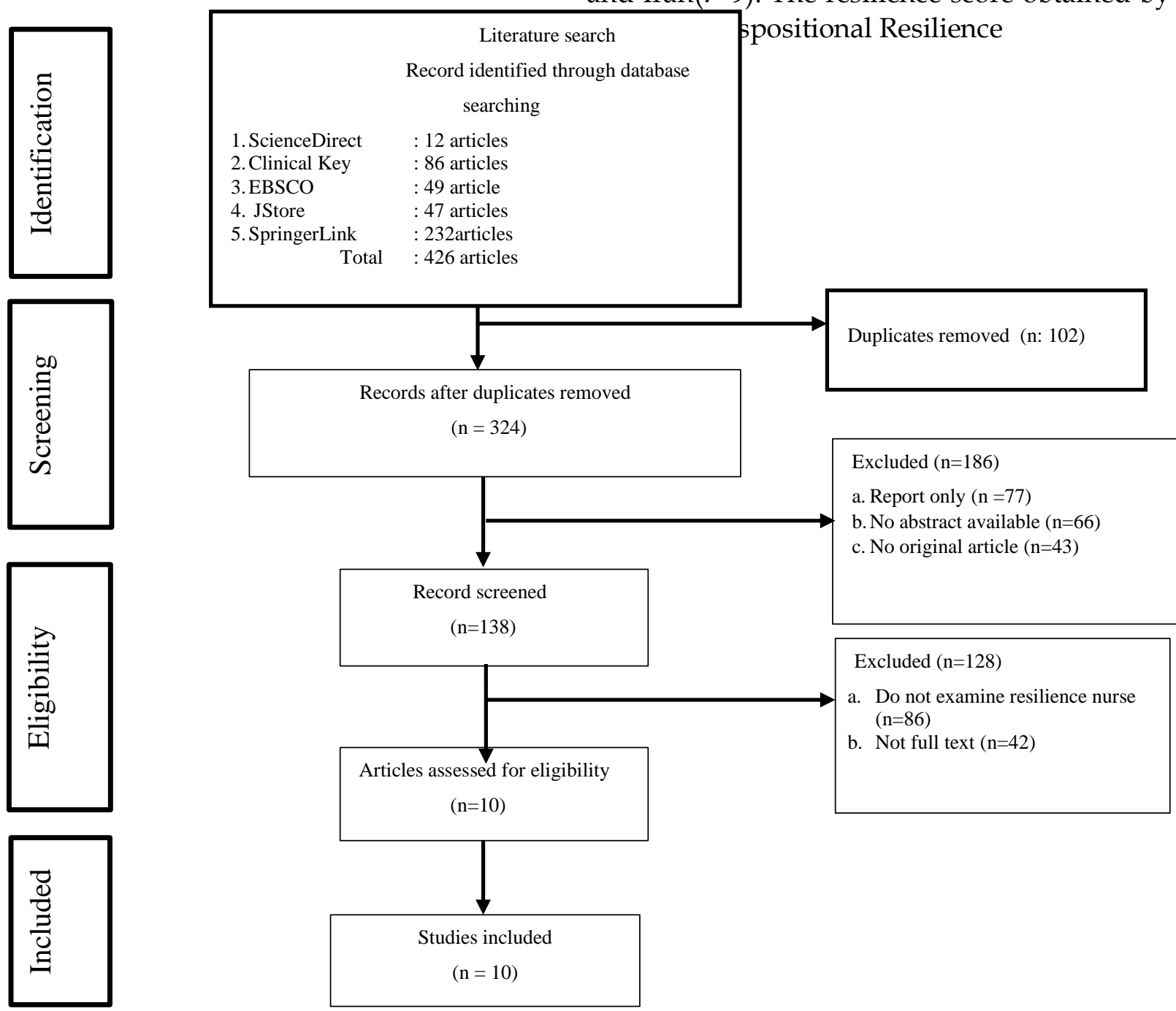

Figure 1. PRISMA Extension for Scoping Reviews (PRISMA-ScR)

The analysis related to nurses' resilience during the COVID-19 pandemic was done on the ten articles. The population mentioned in the articles consists of healthcare personnel, especially nurses.

The analysis related to nurses' resilience during the COVID-19 pandemic was done on the ten articles. The population mentioned in the articles consists of healthcare personnel, especially nurses. The articles summarized some findings related to nurses' resilience during the COVID-19 pandemic: negative stability, signs and symptoms, and the factors' strength.

\section{Theme 1 Negative Resilience}

Three studies discussed negative resilience. The studies used quantitative methods conducted in Spain, the Philippines,
Scale-15 Italian version (DRS-15) showed negative resilience.

On the other hand, research by Barzilay showed some related factors which affect nurses' resilience during the COVID-19 pandemic. The elements were anxiety, worry, and depression. It was found that worry about anxiety and depression was two times increased $p<0.001$ with $\mathrm{OR}=2.23$, while the improvement was noted by $95 \%$. Brazil also revealed that a high level of anxiety and depression shows low resilience, which is characterized as negative (8).

\section{Theme 2 Signs and Symptoms}

Three studies discussed nurses' signs and symptoms of resilience conducted by Moreno et al. $(10,11,17)$. The studies showed International Journal of Nursing and Health Services (IJNHS), Volume 5, Issue 1, February 20 ${ }^{\text {th }}, 2022$ 
signs and symptoms of nurses' resilience during the COVID-19 pandemic. Women experienced stress $(53.7 \%)$ compared to men (35.2\%). Men mainly experienced anxiety, $62.7 \%$ for men and $36.3 \%$ for women. Meanwhile, depression was experienced primarily by women, with $63.37 \%$ for women and $37.73 \%$ for men. The stress is correlated to overwhelming emotion, exhaustion, depersonalization, and the fear of being infected by the virus. Meanwhile, anxiety is related to overwhelming feelings, exhaustion, depersonalization, the fear of family being infected by the virus, and the stress of living in quarantine to keep the family safe from COVID19 , also associated with anxiety. In addition, depression is also correlated with emotional exhaustion, depersonalization, long 12 to 24 hours shift, on-call shifts, living with people at risk, wearing PPE gear for more than 4 hours, and the worry of spreading COVID-19 to the surrounding people (11).

\section{Theme 3 The contributing factors of resilience}

Four studies discussed the factors contributing to resilience, such as education, mental health training, adequate knowledge source, confidence in work accomplishment, active and passive coping. $(12,18)$ Active coping had a positive correlation with active coping $(\mathrm{p}<0.05)$, meanwhile, passive coping was correlated to stress $(p<0.05)$, training, and support were the contributing factors of resilience $(p<0.05)$. Positive resilience could protect nurses from anxiety and depression to maintain mental health. This study also revealed the positive correlation between positive coping strategies and vice versa. Nurses implemented positive coping in every change within the workplace to improve resilience and performance during the COVID19 pandemic $(16,17)$.

\section{DISCUSSION}

Resilience is the ability to reduce the effect of any disturbances by anticipating and preparing to endure and come up after any difficulties. Resilience is also correlated to effective coping, depression, anxiety, and exhaustion as the effects of a sudden incident. COVID-19 pandemic is a stressor for all healthcare personnel, especially nurses. Resilience is a protective factor toward nurses' psychological responses during the COVID-19 pandemic. (11)

In the COVID-19 case, nurses are fully responsible for the patients. However, some worries may be stimulated by prolonged contact with the patient, leading to fear, anxiety, depression, and other psychological responses such as stress. The responses are the effect of the real or immediately perceived threat. Direct contact with COVID-19 patients stimulates anxiety. The anxiety experienced by nurses is the anxious feeling about the possibility of nurses being infected with COVID-19 or unconsciously spreading the virus to others, such as family or the surrounding people. The other source of anxiety is the lack of PPE gear, the fear of storing new coronavirus, the lack of COVID-19 testing kit, the fear of placement in the high-risk area $(7,8)$.

Nurses, especially those who treat COVID-19 patients, must adapt to any changes and immediately come up after any difficulties by implementing more adaptive coping strategies in managing stressors to avoid any unwanted impact such as negative coping. Managing resilience is essential to keep out of negativity which stimulates psychological effects. The psychological impact may affect the performance in providing healthcare. Nurses must improve resilience which further affects thought, emotion, and behavior toward better resilience (9).

Nurses need to strengthen their resilience and coping ability by implementing various strategies. One of the strategies that can be used is social support from colleagues, managers, friends, and family. It could motivate nurses to manage and handle stressful conditions effectively. The support could either reduce the impact of stressors in the workplace or represent a positive correlation between social support and working performance (16).

\section{Acknowledgment}

None

\section{Conflict of interest}

None 
Table 1.1 Matrix of Resilience analysis for nurses during COVID-19 pandemic

\begin{tabular}{|c|c|c|c|c|c|c|}
\hline No & Author & Title & Objectives & Participant & $\begin{array}{l}\text { Research design } \\
\text { and participant }\end{array}$ & Research Result \\
\hline 1 & $\begin{array}{l}\text { Murat } \\
\text { Yildirim, } \\
\text { Gokmen } \\
\text { Arslan, } 2020 \\
\text { (7) }\end{array}$ & $\begin{array}{l}\text { Exploring the } \\
\text { Associations } \\
\text { Between Resilience, } \\
\text { Dispositional Hope, } \\
\text { Preventive } \\
\text { Behaviors, } \\
\text { Subjective Well- } \\
\text { Being, and } \\
\text { Psychological } \\
\text { Health Among } \\
\text { Adults During Early } \\
\text { Stage of COVID-19 }\end{array}$ & $\begin{array}{l}\text { To find out the } \\
\text { correlation } \\
\text { between } \\
\text { resilience, hope, } \\
\text { welfare, and } \\
\text { psychological } \\
\text { health }\end{array}$ & $\begin{array}{l}\mathrm{n}=220 \text { nurses } \\
\text { Male }=134 \\
\text { Female }=86\end{array}$ & $\begin{array}{l}\text { Quantitative study } \\
\text { with cross-sectional } \\
\text { design }\end{array}$ & 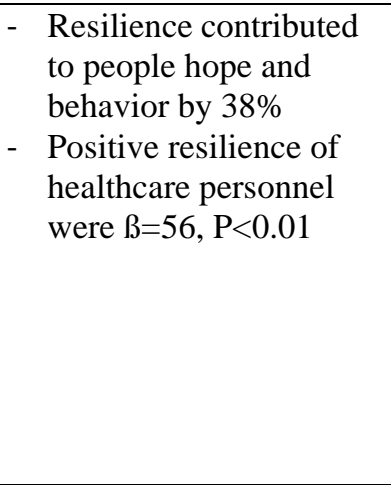 \\
\hline 2 & $\begin{array}{l}\text { Ran Barzilay, } \\
\text { Tyler M. } \\
\text { Moore, David } \\
\text { M. Greenberg, } \\
\text { Grace E. Di } \\
\text { Domenico Lily } \\
\text { A. Brown, } \\
\text { Lauren K. } \\
\text { White Ruben } \\
\text { C. Gur, Raquel } \\
\text { E. Gu, } 2020 \\
\text { (8) }\end{array}$ & $\begin{array}{l}\text { Resilience, COVID- } \\
\text { 19-related stress, } \\
\text { anxiety and } \\
\text { depression during } \\
\text { the pandemic in a } \\
\text { large } \\
\text { population enriched } \\
\text { for healthcare } \\
\text { providers }\end{array}$ & $\begin{array}{l}\text { Evaluating } \\
\text { covid-19 related } \\
\text { stress level }\end{array}$ & $\begin{array}{l}\mathrm{n}=1964 \\
\text { nurses } \\
\text { Female }=1964 \\
\text { Male }=1350\end{array}$ & Quantitative study & $\begin{array}{l}\text { - The participants mainly } \\
\text { worried about the } \\
\text { possibility of the family } \\
\text { being infected by } \\
\text { COVID-19. } \\
\text { - A high level of } \\
\text { resilience means a low } \\
\text { level of anxiety. }\end{array}$ \\
\hline 3 & $\begin{array}{l}\text { Leodoro J } \\
\text { Labrague, } \\
\text { Janet De los } \\
\text { Santos, } 2020 \\
\text { (9) }\end{array}$ & $\begin{array}{l}\text { COVID-19 anxiety } \\
\text { among front-line } \\
\text { nurses: Predictive } \\
\text { role of } \\
\text { organizational } \\
\text { support, personal } \\
\text { resilience, and } \\
\text { social support }\end{array}$ & $\begin{array}{l}\text { To find out the } \\
\text { influence of } \\
\text { personal } \\
\text { resilience, social } \\
\text { support, } \\
\text { organization } \\
\text { support to } \\
\text { reduce anxiety }\end{array}$ & $\mathrm{n}=325$ nurse & $\begin{array}{l}\text { Quantitative study } \\
\text { with cross-sectional } \\
\text { design }\end{array}$ & 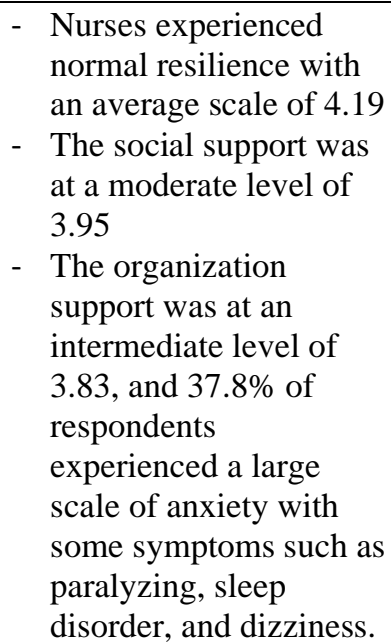 \\
\hline 4 & $\begin{array}{l}\text { Monia } \text { Vagni, } \\
\text { Tiziana } \mathrm{M} \text {, } \\
\text { Valeria } \mathrm{G}, \\
\text { Daniel Pajardi, } \\
2020 \text { (10) }\end{array}$ & $\begin{array}{l}\text { Hardiness, Stress } \\
\text { and Secondary } \\
\text { Trauma in Italian } \\
\text { Healthcare and } \\
\text { Emergency } \\
\text { Personnel during } \\
\text { the }\end{array}$ & $\begin{array}{l}\text { Measuring } \\
\text { healthcare } \\
\text { personnel's } \\
\text { resilience }\end{array}$ & $\begin{array}{l}\mathrm{n}=236 \\
\text { healthcare } \\
\text { personnel } \\
\text { consists of } \\
\text { nurses, } \\
\text { doctors, and } \\
\text { psychologists. }\end{array}$ & $\begin{array}{l}\text { Quantitative study } \\
\text { with cross-sectional } \\
\text { design }\end{array}$ & $\begin{array}{l}\text { - Compared to other } \\
\text { healthcare personnel, } \\
\text { nurses experienced the } \\
\text { highest level of stress. } \\
\text { - } \text { Female nurses } \\
\text { - experienced a higher } \\
\text { level of either emotional } \\
\text { or physical stress. }\end{array}$ \\
\hline
\end{tabular}




\begin{tabular}{|c|c|c|c|c|c|c|}
\hline & & $\begin{array}{l}\text { COVID-19 } \\
\text { Pandemic }\end{array}$ & & & & \\
\hline 5 & $\begin{array}{l}\text { Lourdes } \\
\text { Luceno } \\
\text { Moreno L, } \\
\text { Beatris } \\
\text { Talavera- } \\
\text { Velasco, } \\
\text { Yolanda } \\
\text { García- } \\
\text { Albuerne, } \\
\text { Jesus Martín- } \\
\text { Garcia , 2020 } \\
(11) \\
\end{array}$ & $\begin{array}{l}\text { Symptoms of } \\
\text { Posttraumatic } \\
\text { Stress, Anxiety, } \\
\text { Depression, Levels } \\
\text { of Resilience and } \\
\text { Burnout } \\
\text { in Spanish Health } \\
\text { Personnel during } \\
\text { the } \\
\text { COVID-19 } \\
\text { Pandemic }\end{array}$ & $\begin{array}{l}\text { To analyze post- } \\
\text { trauma stress, } \\
\text { anxiety, and } \\
\text { depression. }\end{array}$ & $\begin{array}{l}\mathrm{n}=1539 \\
\text { healthcare } \\
\text { personnel } \\
\text { consists of } \\
\text { nurses, } \\
\text { doctors, } \\
\text { midwives, and } \\
\text { nutritionists }\end{array}$ & $\begin{array}{l}\text { Quantitative study } \\
\text { with cross-sectional } \\
\text { design }\end{array}$ & $\begin{array}{l}\text { - Stress symptoms } \\
\text { appeared } 39.6 \% \\
\text { - Depression symptoms } \\
\text { appeared } 39.3 \% \\
\text { - Anxiety symptoms } \\
\text { appeared } 40.2 \%\end{array}$ \\
\hline 6 & $\begin{array}{l}\text { Jing Lin, Yun } \\
\text { Hong Ren, } \\
\text { Gan, Ying } \\
\text { Chen, Yin } \\
\text { Fang Huang, } \\
\text { Xue Mei You, } \\
2020(12)\end{array}$ & $\begin{array}{l}\text { Factors associated } \\
\text { with resilience } \\
\text { among } \\
\text { non-local medical } \\
\text { workers sent to } \\
\text { Wuhan, } \\
\text { China during the } \\
\text { COVID-19 outbreak }\end{array}$ & $\begin{array}{l}\text { Analyzing the } \\
\text { correlation } \\
\text { between } \\
\text { resilience with } \\
\text { anxiety, } \\
\text { depression, and } \\
\text { the strategy to } \\
\text { cope with } \\
\text { resilience }\end{array}$ & $\begin{array}{l}\mathrm{n}=116 \\
\text { healthcare } \\
\text { personnel } \\
\text { consists of } \\
\text { nurses, } \\
\text { doctors, and } \\
\text { other }\end{array}$ & $\begin{array}{l}\text { Quantitative study } \\
\text { with cross-sectional } \\
\text { design }\end{array}$ & $\begin{array}{l}\text { - Nurses' resilience score } \\
\text { was lower (64.86) than } \\
\text { doctors' (67.74) } \\
\text { - Resilience, active } \\
\text { coping, anxiety, and } \\
\text { depression were } \\
\text { significantly correlated. } \\
\text { - Occupation, education, } \\
\text { mental health training, } \\
\text { preparation, confidence } \\
\text { in work } \\
\text { accomplishment, } \\
\text { anxiety, depression, } \\
\text { active coping, and } \\
\text { passive coping were } \\
\text { factors that contributed } \\
\text { to the resilience } \\
\end{array}$ \\
\hline 7 & $\begin{array}{l}\text { Elizabeth M } \\
\text { Huffman, } \\
\text { Dimitrios I } \\
\text { Athanasiadis, } \\
\text { Nicolas E } \\
\text { Anton, Lindsay } \\
\text { A Haskett, } \\
\text { Dominique L } \\
\text { Doster, } \\
\text { Stefanidis } \\
\text { Dimitrios, et } \\
\text { al., } 2020(13)\end{array}$ & $\begin{array}{l}\text { How resilient is } \\
\text { your team? } \\
\text { Exploring } \\
\text { healthcare } \\
\text { providers' well- } \\
\text { being } \\
\text { during the COVID- } \\
19 \text { pandemic }\end{array}$ & $\begin{array}{l}\text { To find out the } \\
\text { pandemic effect } \\
\text { on healthcare } \\
\text { providers. }\end{array}$ & $\begin{array}{l}\mathrm{n}=785 \\
\text { healthcare } \\
\text { personnel } \\
\text { consists of } \\
\text { nurses, } \\
\text { doctors, and } \\
\text { other }\end{array}$ & $\begin{array}{l}\text { Quantitative study } \\
\text { with a survey } \\
\text { approach }\end{array}$ & $\begin{array}{l}\text { There were } 55.2 \% \text { of } \\
\text { workers experienced } \\
\text { stress during the } \\
\text { COVID- } 19 \text { pandemic. } \\
\text { - The fear of spreading } \\
\text { the virus to family } \\
\text { members is the primary } \\
\text { source of stress, with } \\
81.6 \% \\
\text { - Participants supported } \\
\text { by the hospital were } \\
56.4 \% \\
\text { - Participants supported } \\
\text { by their unit were } \\
76,7 \% \\
\end{array}$ \\
\hline 8 & $\begin{array}{l}\text { Faruk Bozdag, } \\
\text { Naif Ergun, } \\
2020 \text { (14) }\end{array}$ & $\begin{array}{l}\text { Psychological } \\
\text { Resilience } \\
\text { of healthcare } \\
\text { Professionals } \\
\text { During } \\
\text { COVID-19 } \\
\text { Pandemic }\end{array}$ & $\begin{array}{l}\text { To identify } \\
\text { healthcare } \\
\text { professionals' } \\
\text { psychological } \\
\text { resilience }\end{array}$ & $\begin{array}{l}\mathrm{n}=214 \\
\text { participants } \\
\text { consist of } 66 \\
\text { doctors, } 69 \\
\text { nurses, and } 79 \\
\text { other nursing } \\
\text { department } \\
\text { staff }\end{array}$ & Quantitative study & $\begin{array}{l}\text { Resilience was correlated } \\
\text { to life satisfaction, } \\
\text { positive influence on } \\
\text { social life, preventing the } \\
\text { spread of the virus, and } \\
\text { sleep quality. } \\
\text { - Nurses experienced the } \\
\text { lowest resilience level } \\
\text { with } 17.7 \%\end{array}$ \\
\hline 9 & $\begin{array}{l}\text { Xiao-li xu, Li } \\
\text { Guangyao, } \\
\text { Huang } \\
\text { Shunhong, Liu } \\
\text { Bin, Zhang }\end{array}$ & $\begin{array}{l}\text { The investigation, } \\
\text { Analysis, and } \\
\text { Management }\end{array}$ & $\begin{array}{l}\text { To understand } \\
\text { the mental } \\
\text { resilience and } \\
\text { psychosomatic }\end{array}$ & $\begin{array}{l}\mathrm{n}=165 \\
\text { participants } \\
\text { consist of } \\
\text { nurses, } \\
\text { doctors, and }\end{array}$ & Survey & $\begin{array}{l}\text { Nurses experienced } \\
\text { stressful mental and } \\
\text { physical conditions, } \\
\text { longer working time, } \\
\text { and high-intensity work. }\end{array}$ \\
\hline
\end{tabular}




\begin{tabular}{|c|c|c|c|c|c|c|}
\hline & $\begin{array}{l}\text { Sibling, } 2020 \\
\text { (15) }\end{array}$ & $\begin{array}{l}\text { Application of } \\
\text { Mental Resilience } \\
\text { and } \\
\text { Psychosomatic State } \\
\text { of The Healthcare } \\
\text { Team Against } \\
\text { COVID-19 }\end{array}$ & $\begin{array}{l}\text { status of the } \\
\text { healthcare team. }\end{array}$ & $\begin{array}{l}\text { other } \\
\text { healthcare } \\
\text { personnel }\end{array}$ & & $\begin{array}{l}\text { Nurses tended to } \\
\text { experience difficulties } \\
\text { in working by } 20.5 \% \text {, } \\
\text { compared to doctors } \\
\text { with a proportional } \\
\text { number of } 37.2 \%\end{array}$ \\
\hline 10 & $\begin{array}{l}\text { Tulay Kilinc, } \\
\text { Asli Sis Celik, } \\
2020 \text { (16) }\end{array}$ & $\begin{array}{l}\text { Relationship } \\
\text { between the social } \\
\text { support and } \\
\text { psychological } \\
\text { resilience levels } \\
\text { perceived by nurses } \\
\text { during the COVID- } \\
19 \text { pandemic: A } \\
\text { study from Turkey }\end{array}$ & $\begin{array}{l}\text { To find out the } \\
\text { correlation } \\
\text { between social } \\
\text { support and } \\
\text { psychological } \\
\text { resilience in } \\
\text { nurses }\end{array}$ & $\mathrm{n}=720$ nurses & $\begin{array}{l}\text { Quantitative study } \\
\text { with cross-sectional } \\
\text { design }\end{array}$ & $\begin{array}{l}\text { - Nurse with } 16 \text { years of } \\
\text { working experience had } \\
\text { higher resilience } \\
\text { - Nurses' resilience was } \\
\text { categorized as good } \\
\text { according to Conor } \\
\text { Davidson's scale, which } \\
\text { was } 64.28\end{array}$ \\
\hline
\end{tabular}

\section{REFERENCES}

1. Cleary M, Kornhaber R, Thapa DK, West $S$, Visentin D. The effectiveness of interventions to improve resilience among health professionals: A systematic review. Nurse Educ Today [Internet]. 2018;71(July):247-63. Available from: https:// doi.org/10.1016/j.nedt.2018.10. 002

2. Perry L, Gallagher R, Duffield C, Sibbritt D, Bichel-Findlay J, Nicholls R. Does nurses' health affect their intention to remain in their current position? J Nurs Manag. 2016;24(8):1088-97.

3. Eggenberger SK, Sanders M. A family nursing educational intervention supports nurses and families in an adult intensive care unit. Aust Crit Care. 2016;29(4):217-23.

4. Werneburg BL, Jenkins SM, Friend JL, Berkland BE, Clark MM, Rosedahl JK, et al. Improving resiliency in healthcare employees. Am J Health Behav. 2018;42(1):39-50.

5. Mealer M, Jones J, Newman J, McFann KK, Rothbaum B, Moss M. The presence of resilience is associated with a healthier psychological profile in intensive care unit (ICU) nurses: Results of a national survey. Int J Nurs Stud [Internet]. 2012;49(3):292-9. Available from: http:/ / dx.doi.org/10.1016/j.ijnurstu.201 1.09 .015

6. Arksey H, O'Malley L. Scoping studies: Towards a methodological framework.
Int J Soc Res Methodol Theory Pract. 2005;8(1):19-32.

7. Yildirim M, Arslan G. Exploring the Association Between Resilience, Dispositional Hope, Preventive Behaviours, Subjective Well-Being and Psychological Health Among Adult During Early Stage of COVID-19. Psychology J. 2020;34(4).

8. Barzilay R, Moore TM, Greenberg DM, DiDomenico GE, Brown LA, White LK, et al. Resilience, COVID-19-related stress, anxiety and depression during the pandemic in a large population enriched for healthcare providers. Transl Psychiatry [Internet]. 2020;10(1). Available from: http://dx.doi.org/10.1038/s41398-02000982-4

9. Labrague LJ, De los Santos JAA. COVID19 anxiety among front-line nurses: Predictive role of organizational support, personal resilience and social support. J Nurs Manag. 2020;28(7):1653-61.

10. Vagni M, Maiorano T, Giostra V, Pajardi D. Hardiness and coping strategies as mediators of stress and secondary trauma in emergency workers during the COVID-19 pandemic. Sustain. 2020;12(18).

11. Luceño-Moreno L, Talavera-Velasco B, García-Albuerne Y, Martín-García J. Symptoms of posttraumatic stress, anxiety, depression, levels of resilience and burnout in Spanish health personnel during the COVID-19 pandemic. Int J Environ Res Public Health. 
2020;17(15):1-29.

12. Lin J, Ren $\mathrm{YH}$, Gan HJ, Chen $Y$, Huang YF, You XM. Factors associated with resilience among non-local medical workers sent to Wuhan, China, during the COVID-19 outbreak. BMC Psychiatry. 2020;20(1):1-8.

13. Huffman EM, Athanasiadis DI, Anton NE, Haskett LA, Doster DL, Stefanidis D, et al. How resilient is your team? Exploring healthcare providers' wellbeing during the COVID-19 pandemic. Am J Surg [Internet]. 2020; (xxxx). Available from: https:// doi.org/10.1016/j.amjsurg.2020. 09.005

14. Bozdağ F, Ergün N. Psychological Resilience of Healthcare Professionals During COVID-19 Pandemic. Vol. 124, Psychological Reports. 2021. p. 2567-86.

15. Xu X, Guangyao L, Shunhong H, Bin L, Sibling Z. Investigation, Analysis and Management Application of Mental Resilience and Psychosomatic State of The Medical Team Against COVID-19. 2020;19.

16. Kılınç T, Sis Çelik A. Relationship between the social support and psychological resilience levels perceived by nurses during the COVID-19 pandemic: A study from Turkey. Perspect Psychiatr Care. 2020;(June):1-9.

17. Li Q, Guan X, Wu P, Wang X, Zhou L, Tong $Y$, et al. Early Transmission Dynamics in Wuhan, China, of Novel Coronavirus-Infected Pneumonia. N Engl J Med. 2020;382(13):1199-207.

18. Angrianita H. Kebutuhan Pasien Kanker Dewasa dan Keluarga dalam Perawatan Palliatif Berbasis Patient-Centered Care di RSUP Nasional Dr. Cipto Mangunkusumo. Program Pasca Sarjana Fakultas Kedokteran Universitas Gadjah Mada Yogyakarta; 2017. 